\title{
Web Services Technology Using Liquefied Petroleum Gas (LPG) Availability Coding On The Distribution Area Map To Reach The Community
}

\author{
Deril Alfiance Kaligis ${ }^{1}$, Teddy Istanto ${ }^{2}$ \\ Informatics Engineering Department \\ Universitas Musamus \\ Merauke, Indonesia \\ 1alfiankaligis1@gmail.com, ${ }^{2}$ istanto@unmus.ac.id
}

\begin{abstract}
Displacement of kerosene to Liquefied Petroleum Gas (LPG), giving a positive impact as one of the staples in several respects. Viewed from the increasing demand for gas fuel (Liquefied Petroleum Gas), government through Pertamina launched a system to monitor the process of distribution of liquefied petroleum gas which of course is expected to meet the needs of the various elements of society, as well as monitor every distribution process. The truth is, LPG distribution monitoring system is considered still cannot cover up the station, retailer especially the lack of service to the community, which is a monitoring map that displays the number of the stock of LPG. The objective of this journal is to create a web service technology using LPG availability coding in the distribution area to reach the community so it can provide services to all elements of society. The design of these applications used the Personal Home Page (PHP) programming language and database using My SQL. The method used in the design is the structured design method, and the testing method used is the Black-box method and questionnaire. Distribution monitoring system utilizes web service technology, which can accessed at all elements of society and availability information of LPG stock at each agent, station, and retailers which can be accessed by all elements of society in the form of a code of the location, address and the amount of availability.
\end{abstract}

Keywords-Liquefied Petroleum Gas; Personal Home Page; MySQL 2015

\section{INTRODUCTION}

A need is a condition characterized by the feeling of deprivation and wanting to get something realized through an effort or action. In this aspect, humans are social beings who need other parties to seek problem-solving, and also to continue their lives. Problem-solving requires information. information technology are a facility-infrastructure (hardware, software, useware) system, and a method for obtaining, sending, processing, interpreting, storing, organizing, and using data meaningfully. Based on the Presidential Regulation (2012)[1], the transfer of the use of the oil fuel (BBM) to the gas fuel is one of the alternative fuels which are safe, clean, reliable, and cheap, to produce fewer emissions than gasoline, and to increase national energy security, both short and longterm.
LPG (Liquefied Petroleum Gas) needs are also increasing and evenly distributed throughout the regions in Indonesia. The availability of LPG (Liquefied Petroleum Gas), in every agent to the base, is considered unable to provide facilities to determine the available stock of LPG (Liquefied Petroleum Gas) tube gas without having to wait for the information or reports from the agent or even sub-agent/base, in the form of monitoring maps that raise the data on the amount of LPG (Liquefied Petroleum Gas) stock. Based on the data obtained through the survey method, in the form of interviews with questionnaires and secondary data collection from related agencies, [2], the researcher concludes that there is a need to provide a WEB-based monitoring system that can be accessed on a PC computer or mobile phone, that can connect Pertamina, agents, bases, and the public, without affecting user requirements and performance, and maintaining data confidentiality. The design of this application uses the programming language Personal Home Page (PHP), with the database using My SQL.

The purpose of research and design is to provide an online-based medium of stock information on each agent and base, with additional monitoring maps; and not only accessed by certain parties, but also related to the letter symbols on the monitoring map, in the form of letter codes that can change color to red or green according to the available existing LPG (Liquefied Petroleum Gas) stock. The output of this monitoring map is made to facilitate the public in finding the nearest LPG (Liquefied Petroleum Gas) location and the amount of available stock at the base or even retailer, if there is a shortage of LPG (Liquefied Petroleum Gas) at the location around the community who turns out to be the main consumers. 


\section{METHOD}

The system is built based on the distribution channel of LPG (Liquefied Petroleum Gas). The LPG distribution channel shown on Fig 1.

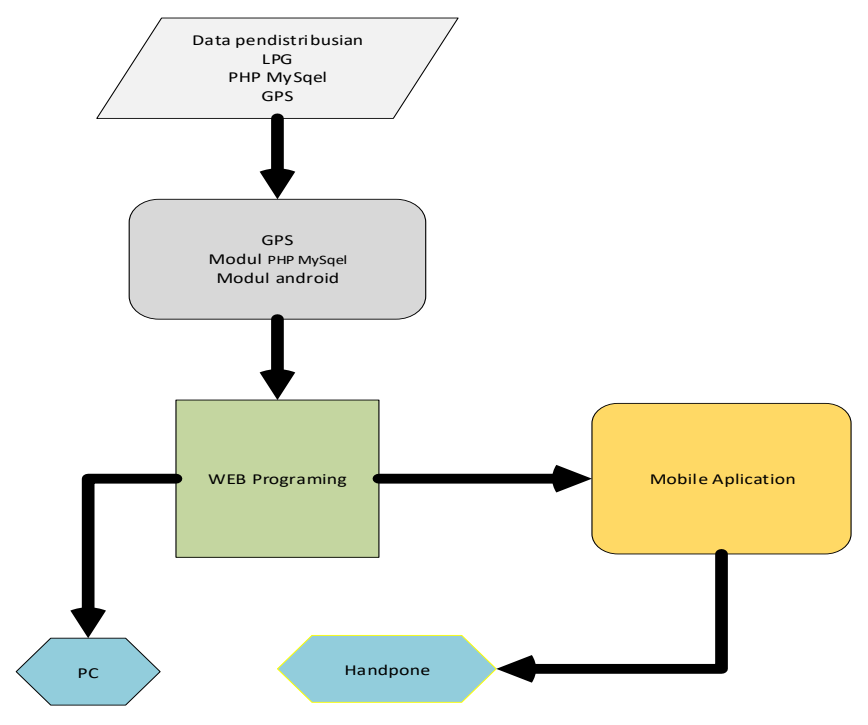

Fig. 1. Liquefied Petroleum Gas (LPG) Monitoring System Block Diagram

The research procedure conducted by researchers uses several stages. First is the analysis of infrastructure models. At this stage, the research focuses on identifying each problem and its complexity, based on the real model image and occurring in the field. This stage also discusses additional technologies that will be used, such as the Android database, network architecture applications, and mapping technology as an addition. Second is the data collection and literature study. At this stage, researcher collects the input data for the system, and output from the system, to be processed into information. In literature studies, there are many literature studies referring to domestic and foreign references. Third is System Design and the Design. At this stage, researcher designs the interfaces for the LPG distribution monitoring systems. Figure-2 describes the overall system flow, building the Web with PHP and MySQL. Finally, the system testing: the system is tested using the black box testing techniques. Every functional in the system is tested for its performance to get the good quality in performance [3].

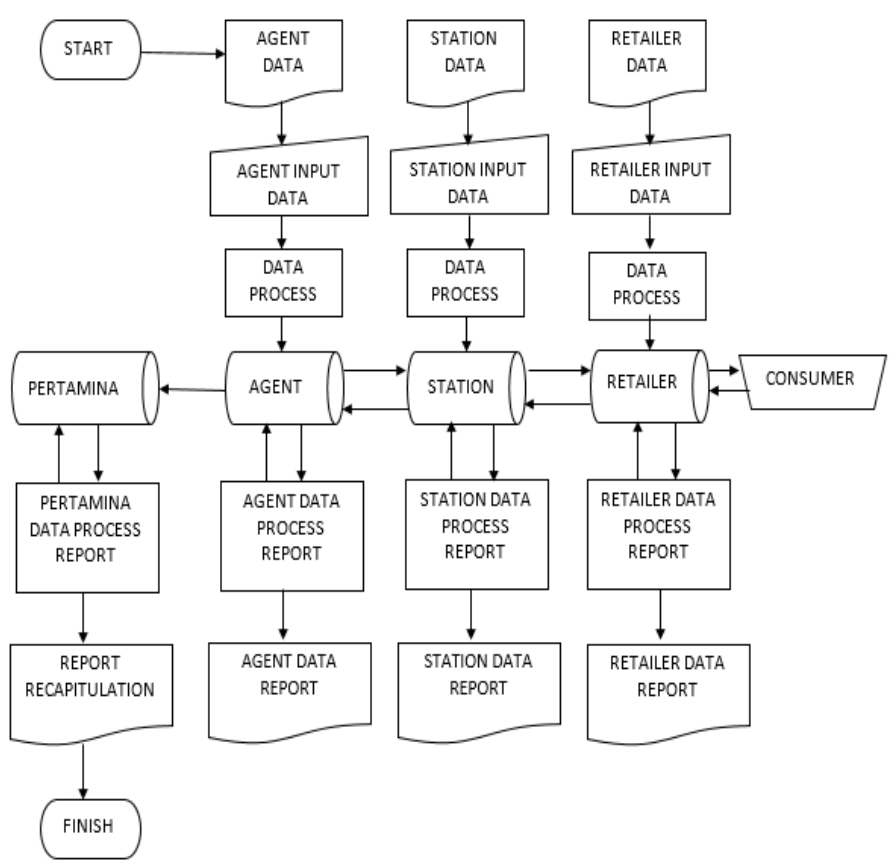

Fig. 2. The flow system of LPG (Liquefied Petroleum Gas)

\section{RESULT AND DISCUSSION}

This research was conducted in Makassar, South Sulawesi, for 10 months, starting from December 2015 to October 2016. The data used in this research is an LPG document, obtained from PT. PERTAMINA PERSERO Makassar, and in-the-field interview results, with the handling of LPG from Pertamina and parties from several LPG agents in Makassar. Secondary data is the search for as much literature as possible, both from books, internet, and journal references or related research reports, and other sources considered supporting the research [2].

Specifically, mobile phone is used for the public, generally to find the nearest and-still-available LPG (Liquefied Petroleum Gas) location. The mobile phone used must be an Android OS-based one. The mobile phone used in this research is OPPO Neo 5 Type-1201 which is supported by GSM network: $800 / 900 / 1900 \mathrm{Mhz}$, designed by OPPO, made in Indonesia. The PC used here is the Lenovo E10-30, the Chinese model.

Based on the design, the system produces a distribution of LPG (Liquefied Petroleum Gas) distribution system monitoring which not only can be accessed by specific users but there are parts that could be accessed by the public in real time. First, Figure 3, the system can monitor the distribution of LPG (Liquefied Petroleum Gas) stocks distributed, so that a comparison of agent purchases with the number of LPG gas cylinders is obtained. 


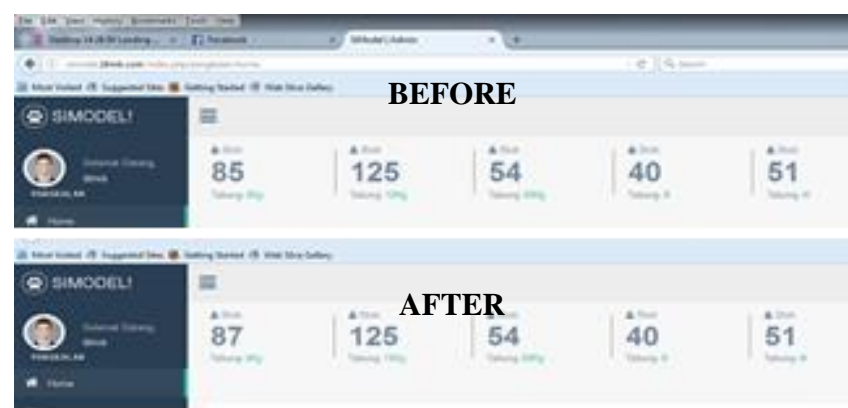

Fig. 3. System can display charts of LPG (Liquefied Petroleum Gas) supply per day for PERTAMINA, agents and LPG (Liquefied Petroleum Gas) station.

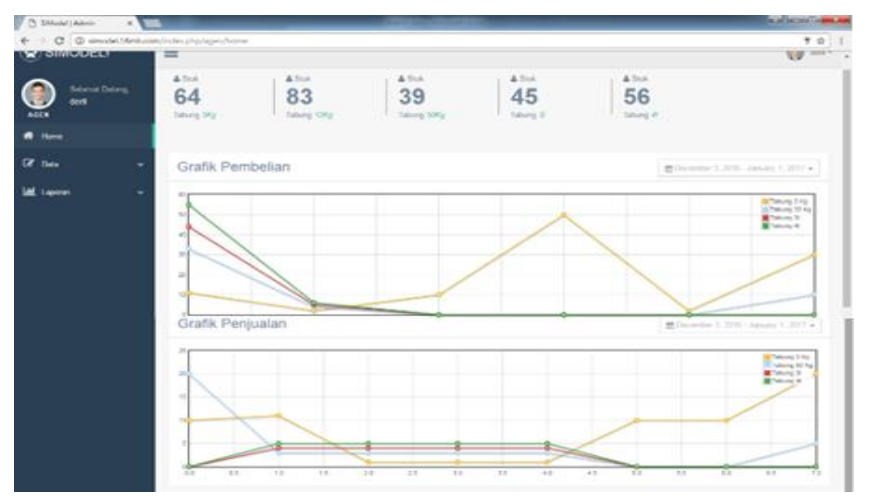

Fig. 4. LPG Monitoring Chart Provision of monitoring map.

LPG Monitoring Chart Provision of monitoring map. Also generate benefits for society in order to generate information from the agent, station, and retailers of LPG and the availability of nearby gas owned. Their monitoring map helps in the scarcity of LPG which is nearby and still available [3]. Display of stock on the map displays the symbol letter A for LPG agents, PK for LPG bases, and P for LPG retailers. This symbol is given a color code that is green to indicate the stock is still available and the color is red to indicate the stock has run out. Following is the display of LPG gas distribution monitoring map, on the monitoring map is divided into 2 display models namely:

- Satellite view

- Google Maps

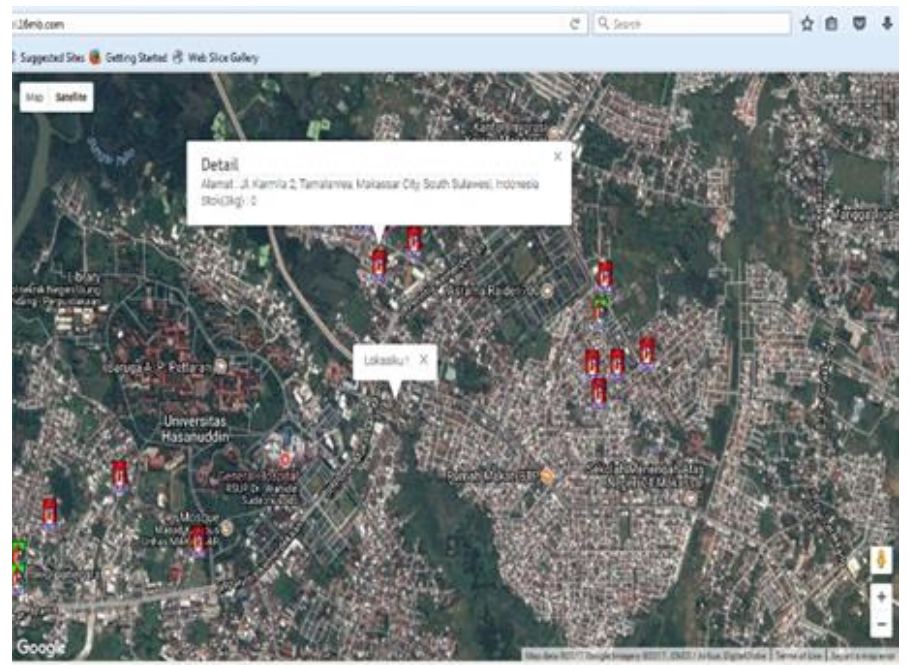

Fig. 5. Map of LPG (Liquefied Petroleum Gas) Monitoring by satellite

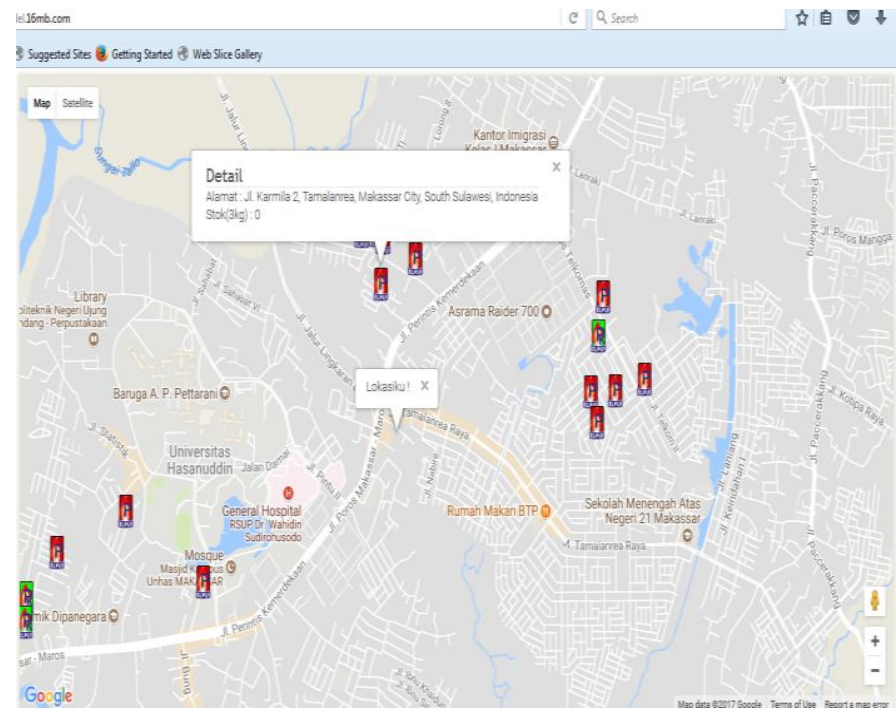

Fig. 6. Map of Liquefied Petroleum Gas Monitoring by Google Maps

Besides displaying the system in pc computer and notebook in Figure 3, Figure 4 and Figure 5, Figure 6 Map of LPG (Liquefied Petroleum Gas), system that has been made can also be displayed on mobile phone. Here are the results of the display on the mobile phone: 


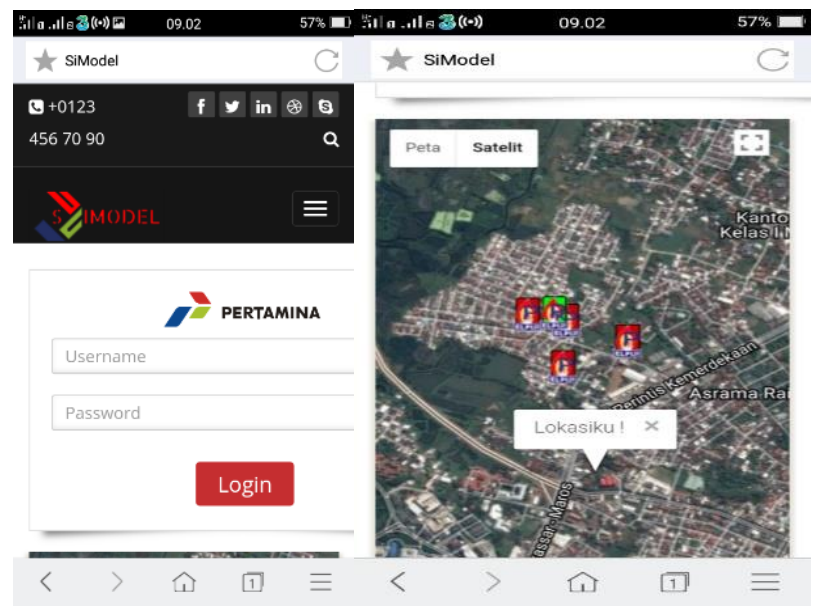

Fig. 7. User Form Login System monitoring and Map of LPG (Liquefied Petroleum Gas) Monitoring

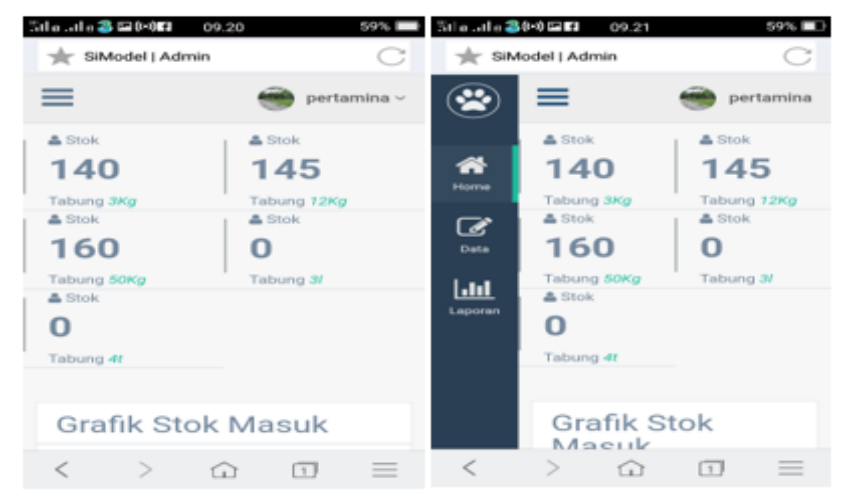

Fig. 8. The system main form

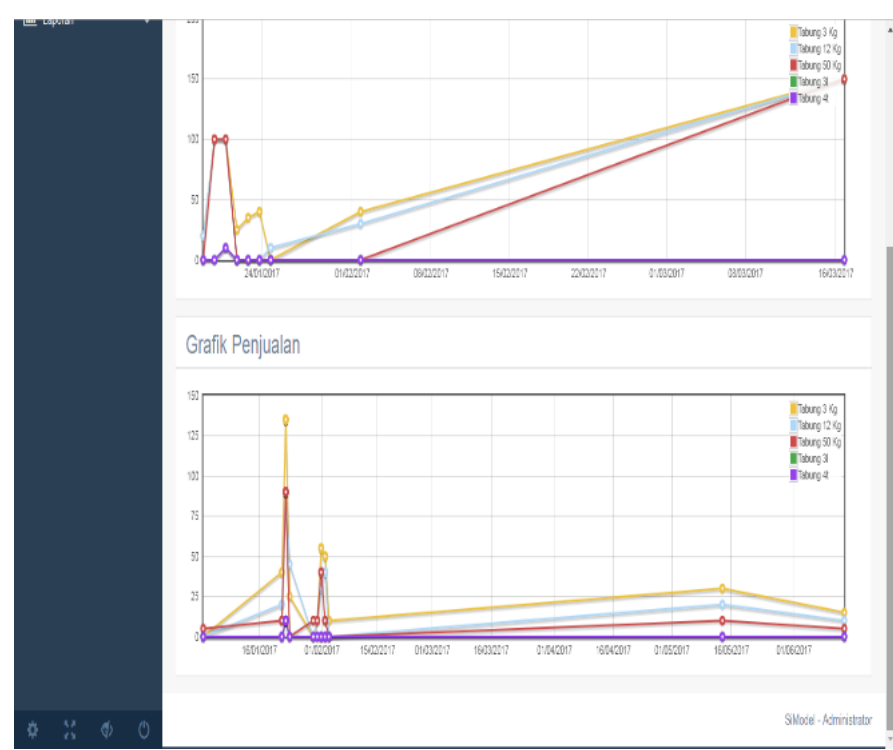

Fig. 9. The graph of entry stock and sales on the system
Figure 9 shows a graph that has the following meanings:

- Import chart

Indicates the amount of LPG (Liquefied Petroleum Gas) imported (Vertical line) and the date of import stock entry.

- Sales charts

Shows the number of stocks of LPG (Liquefied Petroleum Gas) sold (vertical lines) and the date the stock is sold.

Another result obtained on the system is the sale of LPG (Liquefied Petroleum Gas) report. The report can be printed out. For example, this is the result of a report view obtained by the monitoring system of LPG (Liquefied Petroleum Gas) distribution of PERTAMINA to the sale of the agent/agency stock report:

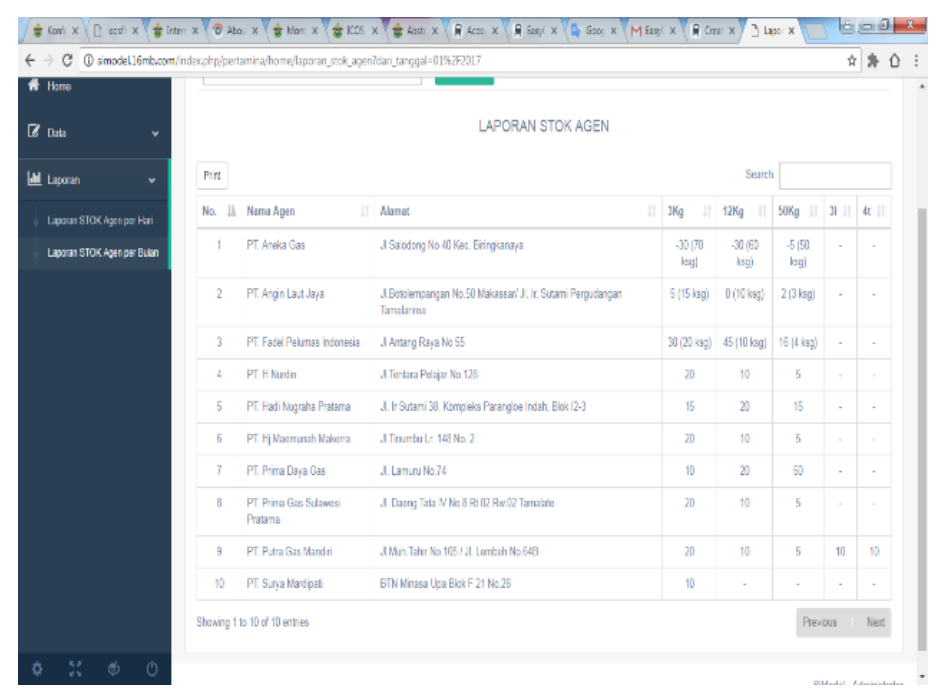

Fig. 10. Stock agent report

\section{CONCLUSION}

Based on the finished research about the "LPG Distribution Online Monitoring System in Makassar," researcher can conclude these:

1. This LPG (Liquefied Petroleum Gas) distribution monitoring system can monitor up to the time LPG (Liquefied Petroleum Gas) has been received by agents, bases, and retailers, in the form of tubes $3 \mathrm{~kg}$, tubes 12 $\mathrm{kg}$, tubes $50 \mathrm{~kg}$, tubes 31 , 4t tubes

2. This LPG (Liquefied Petroleum Gas) distribution monitoring produces reports that can be printed from each LPG (Liquefied Petroleum Gas) distribution process.

3. This LPG (Liquefied Petroleum Gas) distribution monitoring system also provides monitoring map services that show the number of LPG (Liquefied Petroleum Gas) stocks in each agent, base, and retailer. The resulting monitoring map is also able to display the location of the nearest LPG (Liquefied Petroleum Gas) system users and providers, so that system users can 
easily see the location of the nearest agent, base, and retailer, as well as the amount of stock held.

\section{ACKNOWLEDGMENT}

We thank Universitas Musamus for facilities, supports, and publications.

\section{REFERENCES}

[1] B. Internasional, U. Rekonstruksi, and D.A.N. Pembangunan, Lembaran Negara, no. 10, pp. 2-4, 1966.

[2] S. Joey, "Virtual Viclab untuk Pelajar SMA Berbasis Android Menggunakan LIBGDX Stevanie Joey," unpiblished.

[3] R.S. Pressman, Software Engineering: a Practioner's Approach, vol. 33, 2010.

[4] I. Masudin, "Facility Location Modeling in Multi-EchelonDistribution System: A Case Study of Indonesian Liquefied Petroleum Gas Supply Chain,” Aceh Inter. J. Sci. Tech., vol. 2, 2013.

[5] N.P.A. Nariswari and I.N. Pujawan, Simulasi Penerapan Closed System Pada Distribusi Elpiji $3 \mathrm{Kg}$, Surabaya: Institut Teknologi Sepuluh Nopember, 2011.

[6] R. Setia, Pembuatan Aplikasi Sistem Monitoring Distribusi Pupuk Dan Benih Bersubsidi Menggunakan Kartu Kendali Di Departemen Pertanian, Jakarta Timur: Universitas Gunadarma, 2009. 